\title{
Copper nanoparticles as modulator of active bacterial population and their physiology in ecosphere
}

\author{
Ali Alboloushi ${ }^{\mathrm{a}}$, Absar Alum $^{\mathrm{b}}$, Morteza Abbaszadegan ${ }^{\mathrm{b}}$ \\ ${ }^{a}$ Environmental Technology Management Department, College of Life Sciences, \\ Kuwait University \\ ${ }^{b}$ Water and Environmental Technology Center \\ Fulton Schools of Engineering \\ School of Sustainable Engineering and the Built Environment \\ Arizona State University
}

\begin{abstract}
The widespread use of nanoparticles (NPs) in industrial and consumer products has resulted in their emergence as significant environmental contaminants that can potentially modulate the role of bacteria in environment.-This study examines the impact of different sizes of Copper nanoparticles (CuNPs) on the population and physiology of environmentally relevant gram positive (Bacillus) and gam negative (Alcaligenes, and Pseudomonas) bacteria. In general, exposure to CuNPs resulted in 4 to $>6 \log$ inactivation in bacterial population. More specifically, after $2 \mathrm{hr}$ exposure of Alcaligenes and Pseudomonas to 50 CuNPs, 5.75 and 6.64 log reduction noted, respectively; and their exposure to $100 \mathrm{CuNPs}$ resulted in 5.97 and $6.58 \mathrm{log}$ reduction, respectively. A similar exposure of laboratory and environmental isolates of Bacillus to 50 and $100 \mathrm{CuNPs}$ resulted in $4.84,4.16$ and $4.35,3.61$ log reduction, correspondingly. The exposure induced elicitation of different toxicity pathways in the test bacteria. Bacterial exposure to $50 \mathrm{CuNPs}$ resulted in elevated levels of LDH in Pseudomonas, in contrast these levels decreased in Alcaligenes and Bacillus. Our toxicity studies showed that exposure to CuNP can have various levels of metabolic and cellular modulation in bacterial species, suggesting that the presence of CuNPs in
\end{abstract}


environment can potentially impact the pollutants-attenuation-role of bacteria in environments such as wastewater biological treatment processes.

KEYWORDS: Copper Nanoparticles, Bacillus, Alcaligenes, Pseudomonas, toxicity mechanism

\section{Introduction}

Widespread use of nanoparticles (NPs) in agricultural, industrial and consumer products results in the release of huge quantities of NPs in environment. The NPs species have been recognized as significant contaminants in wastewater and sludge (EPA 2003; Roco 2007; Westerhoff et al., 2009). They are known to impact biological activities at molecular, cellular, organism/system??, and ecological levels (Aruoja, et al., 2015; Bhuvaneshwari, 2016; Joonas et al., 2019; Ren et al., 2009). Unabated release of heavy metal-containing nanoparticles (mNPs) into the wastewater can have detrimental consequences on the normal bio-ecological processes. Increased prevalence of mNPs can potentially alter a range of ecologically beneficial roles played by bacteria, including the normal function of wastewater treatment processes, natural attenuation of pollutants and mineral cycling. The functional role of mNPs in the ecological processes have been broadly studied under laboratory and small-scale field studies; there is a need for investigating these impacts under well-defined experimental conditions (Alum et al., 2018).

Copper nanoparticles (CuNPs) are widely used in industrial applications such as semiconductors, heat transfer fluids in machine tools, metal catalysts, and even in the area of public health as biocidal preparations (Aruoja et al., 2009; Kim et al., 2011). 
In addition, a large amount of CuNPs is continuously released from the automobile brake systems (Denier et al., 2007; Grigratos and Matini 2015). These facts make CuNPs a good candidate for studying their potential adverse effects on bio-geoecology of surface and waste waters (Brown et al., 1995; Gilbertson et al., 2016).

The objective of this study was to investigate the adverse impacts of CuNPs on the laboratory isolates of Bacillus, Alcaligenes, and Pseudomonas and field isolates of Bacillus. The study also measured the role of various environmental conditions, such as $\mathrm{pH}$, temperature, and light exposure on the mNPs role in environment.

\section{Materials and Methods}

\section{Bacterial Strains}

Pure cultures of Bacillus subtilis (ATCC 23059), Alcaligenes faecalis (ATCC 8750), and Pseudomonas aeruginosa (ATCC 10145) were obtained from the American Type Culture Collection (ATCC, Rockville, MD). A Bacillus isolate from a local wastewater lagoon (Maricopa, AZ) was included in the study as a representative of environmental isolates for comparison purposes. The identity of environmental isolate was confirmed by molecular analyses such as polymerase chain reaction (PCR) and sequencing (data not shown).

\section{Culture Preparation}

Working cultures of the selected bacteria were prepared by inoculating $0.1 \mathrm{ml}$ of the over-night culture in $9.0 \mathrm{ml}$ of the nutrient broth and incubated in a shaker-incubator (New Brunswick Scientific C24, Edison, NJ) (150 RPM @ 37 $\left.{ }^{\circ} \mathrm{C}\right)$. Cultures were grown to an optical density of 0.8 to 1.0 at $600 \mathrm{~nm}$, measured using a 
spectrophotometer (Hach DR/4000U, Loveland, CO). Bacterial cells were harvested by centrifugation at $1500 \mathrm{xg}$ for $10 \mathrm{~min}$; supernatants were discarded, and pellets were re-suspended in phosphate buffer (0.5M PBS).

\section{Characteristics of Copper Nanoparticles}

The CuNPs included in this study were spherical in shape with a diameter of 50 nanometer (50 CuNP) (Cat\# 684007) and 100 nanometers (100 CuNP) (Cat\# 634220) (Sigma Aldrich, Saint Louis, MO). Both types of CuNPs species have similar physicochemical characteristics including density $(8.94 \mathrm{~g} / \mathrm{mL})$; resistivity $(1.673 \mu \Omega$ $\mathrm{cm}$ at $\left.20^{\circ} \mathrm{C}\right)$; surface area $\left(5-10 \mathrm{~m}^{2} / \mathrm{g}\right)$ and surface charge $(+33 \mathrm{mV})$. Identical physicochemical properties of both test CuNPs permitted to delineate the impact of particle size on their biological impact. Stocks of test CuNPs were kept at room temperature and suspended in PBS as needed. The distribution of CuNPs in reactor solution was determined by Dynamic Light Scattering technique and polydispersity index of 0.225 and 0.057 was recorded for sonicated stock and reactor sample.

\section{Bacterial Exposure to CuNPs}

Exposure experiments were conducted in an axially rotating mixer (Rotamix, ATR Inc. Laurel, MD) operated at 40 RPM to ensure constant and even dispersal of CuNPs in the reaction volume throughout the experiment. In the exposure studies, use of the axially rotating mixer is critical as CuNPs tend to settle down in the peripheral zone of a stir mixer.

Each type of NPs (50 CuNPs and $100 \mathrm{CuNPs}$ ) was added to the individual reactor at a final concentration of $6 \mathrm{mM}(0.0036 \mathrm{mg}$ per10 $\mathrm{mL})$.

Total number of 50 CuNPs in each reactor $=($ total mass $) \times(\text { density })^{-1} \mathrm{x}(\text { volume })^{-1}$ 


$$
\begin{aligned}
& =(0.0036 \mathrm{mg}) \times\left(1 \times 10^{21} \mathrm{~nm}^{3}\right) \times(8.94)^{-1} \times(1,000 \mathrm{mg})^{-1} \times\left(6.5 \times 10^{4} \mathrm{~nm}^{3}\right)^{-1} \\
& =6.2 \times 10^{9} 50 \mathrm{CuNPs}
\end{aligned}
$$

Total number of 100 CuNPs in each reactor $=($ total mass $) \times(\text { density })^{-1} \mathrm{x}(\text { volume })^{-1}$

$=(0.0036 \mathrm{mg}) \times\left(1 \times 10^{21} \mathrm{~nm}^{3}\right) \times(8.94)^{-1} \times(1,000 \mathrm{mg})^{-1} \times\left(5.2 \times 10^{5} \mathrm{~nm}^{3}\right)^{-1}$

$=7.7 \times 10^{8} 100 \mathrm{CuNPs}$

Exposure experiments were conducted in individual reactors containing 50 or $100 \mathrm{~nm}$

CuNPs spiked with washed bacteria at a concentration of $1 \times 10^{9} \mathrm{CFU} / \mathrm{mL}$. The control reactor was operated under similar experimental conditions with no CuNPs added.

Samples were collected at 20, 40, 60, 90, and 120 min contact time from each reactor and analyzed in duplicate assays for viable bacterial counts using membrane filtration.

\section{Membrane Filtration for Bacteria}

Samples were analyzed for target bacteria by filtering samples through a $47 \mathrm{~mm}$ cellulose acetate membrane with $0.47 \mu$ m pore size. Each membrane was placed on appropriate selective agar media plate and incubated at $37^{\circ} \mathrm{C}$ for $24-48$ hours. After the incubation, colonies were counted and recorded as viable bacterial counts for each exposure time.

\section{CuNP Toxicity Pathways}

The toxicity of CuNPs was studied by examining their; 1) interaction with the ligands on bacterial cell surface; 2) impairment cellular defense mechanisms; 3) interference with the cellular energy pathways. Washed bacterial cells were exposed to CuNPs for a specified time and exposed cells were analyzed for the metabolic activities 
including lactic dehydrogenase, glutathione reductase enzyme and $\mathrm{NAD}(\mathrm{P}) \mathrm{H}-$ dependent oxidoreductase.

\section{Lactic Dehydrogenase Assay}

After exposure to CuNPs, damage to bacterial cell membrane was determined using the Lactic Dehydrogenase based Cellular In Vitro Toxicology Assay Kit, (SigmaAldrich, Saint Louis, MO). The assay was performed according to the manufacturer's instructions with slight optimization for detecting the total LDH in bacteria cells and samples suspension.

\section{Glutathione Reductase Assay}

The glutathione reductase (GR) enzyme protects cells against radicals. The level of GR in CuNPs exposed cells were determined using the Glutathione Assay Kit, (Cayman Chemical Company, Ann Arbor, MI). The analyses were performed according to the manufacturer's instructions. The absorbance readings for GR activity were normalized using the equation provided in the GR assay protocol:

The actual extinction coefficient for NADPH at $340 \mathrm{~nm}$ adjusted for the path length of the solution in the cuvette $=0.00622 \mu \mathrm{M}^{-1} \mathrm{~cm}^{-1} \mathrm{x} 1 \mathrm{~cm}=0.00622$

\section{MTT Assay}

The integrity of energy cycle in the CuNPs exposed bacterial cells was determined by quantify the activity of $\mathrm{NAD}(\mathrm{P}) \mathrm{H}$-dependent oxidoreductase. The assay was performed using the MTT Cell Proliferation Assay Kit obtained from American Type Culture Collection (ATCC) (Manassas, VA). The kit was used according to the manufacturer's instructions. 


\section{Scanning Electron Microscope}

The physical impact of $50 \& 100 \mathrm{~nm}$ CuNPs on the Bacillus cells was visualized using scanning electron microscope (SEM) (Focused Ion Beam - Nova 200 NanoLab - FEI) (Hillsboro, OR). The bacterial cells exposed to $50 \& 100 \mathrm{~nm}$ CuNPs were deposited on aluminum stud and coated with gold using sputter coater (Denton Vacuum) (Moorestown, NJ). The samples were observed under the scanning electron microscope to locate CuNPs inside Bacillus cells. As a control, non-treated Bacillus cells were identically processed and visualized. The treated and control samples were observed under SEM with XLD scan capabilities that allowed to detect the CuNPs inside the bacterial cell using $\mathrm{Cu}$ specific peaks in XLD scans.

\section{Release of $\mathrm{Cu}^{2+}$ from CuNPs}

The kinetics of the $\mathrm{Cu}^{2+}$ release from $50 \& 100 \mathrm{~nm}$ CuNPs in aqueous solution $(0.5 \mathrm{M}$ PBS buffer) was studied using Cupric Ion Selective Electrode ( $\mathrm{Cu}^{2+}$-ISE) (ColeParmer, Vernon Hills, Illinois). The release of $\mathrm{Cu}^{2+}$ were studied under different conditions including light exposure, temperature, contact time, and medium acidity. The Cupric Ion Selective Electrode was used according to the manufacturer's instructions. $\mathrm{Cu}^{2+}$ complex formation was studied in 0.5M PBS and nano-pure water and calibration curves for both solutions were generated.

\section{Results and Discussion}

\section{Bacterial Inactivation by CuNPs}

The impact of $50 \& 100 \mathrm{~nm}$ CuNPs on environmentally important gram-negative and gram-positive bacterial isolates was investigated. After short exposures to 50 and 100 
CuNPs, Bacillus, Alcaligenes, and Pseudomonas showed differences in inactivation kinetics; however, after 120 min exposure, the cumulative bactericidal effect of both type of CuNPs appears to reach the same rate (Figure 1). The highest bactericidal effect of 50 and 100 CuNPs against laboratory isolates of Alcaligenes, and Pseudomonas was noted at $90 \mathrm{~min}$. Whereas, for Bacillus the bactericidal effect peaked at 60 and $40 \mathrm{~min}$ for 50 and $100 \mathrm{CuNPs}$, respectively (Table 1).

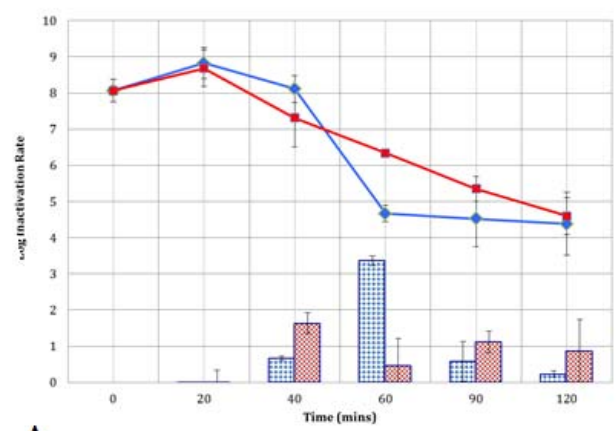

$\mathbf{A}$

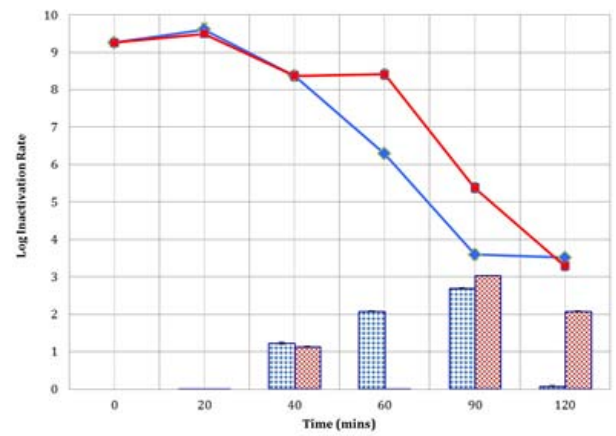

C

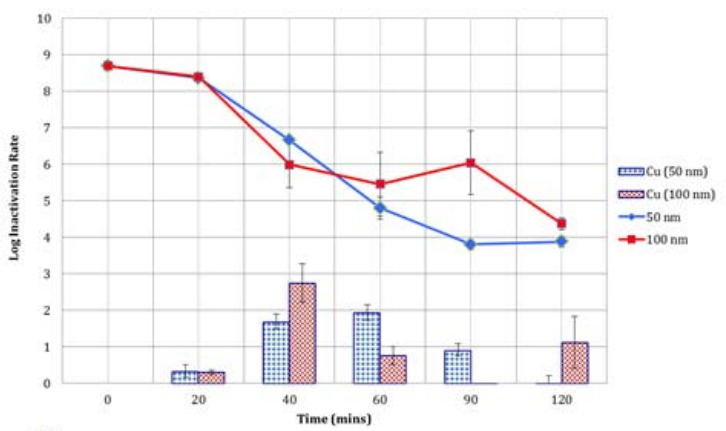

B

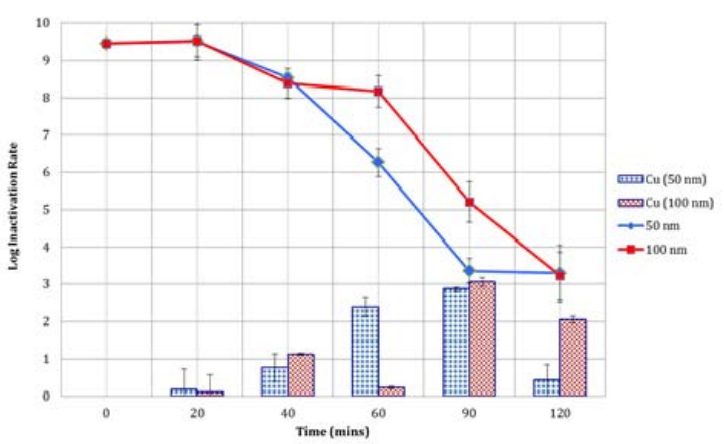

D

Figure. 1. Bactericidal effects of 50 and 100 CuNPs on: A) Bacillus the laboratory isolate, B) Bacillus isolate from wastewater, C) Alcaligenes laboratory isolate, D) Pseudomonas laboratory isolate.

Note: The line graphs represent accumulative inactivation and the bar graphs represent inactivation between time intervals.

Table 1. Inactivation of laboratory and environmental isolates of G+ and G- 


\begin{tabular}{|c|c|c|c|c|}
\hline \multicolumn{5}{|l|}{ bacteria using 50 and $100 \mathrm{CuNPs}$} \\
\hline \multirow[t]{2}{*}{ Bacterial Species } & \multicolumn{2}{|c|}{$\begin{array}{c}\text { Peak Inactivation } \\
(\text { min) }\end{array}$} & \multicolumn{2}{|c|}{$\begin{array}{c}\text { Total Reduction } \\
\log _{10}\end{array}$} \\
\hline & $\begin{array}{c}50 \\
\text { CuNPs }\end{array}$ & $\begin{array}{c}100 \\
\text { CuNPs }\end{array}$ & $\begin{array}{c}\mathbf{5 0} \\
\mathrm{CuNP} \\
\mathrm{s}\end{array}$ & $\begin{array}{c}100 \\
\text { CuNPs }\end{array}$ \\
\hline Bacillus (Laboratory Isolate) & 60 & 40 & 4.16 & 3.61 \\
\hline Bacillus (Wastewater Isolate) & 60 & 40 & 4.84 & 4.35 \\
\hline Alcaligenes (Laboratory Isolate) & 90 & 90 & 5.75 & 5.97 \\
\hline Pseudomonas (Laboratory Isolate) & 90 & 90 & 6.64 & 6.58 \\
\hline
\end{tabular}

\section{Biocidal efficacy of CuNPs in Wastewater}

The bactericidal efficacy of 50 and 100 CuNPs were investigated in primary and secondary treated wastewater samples. In primary treated wastewater, after $2 \mathrm{hr}$ exposure to 50 or $100 \mathrm{~nm}$ CuNPs, the concentration of bacteria decreased from 6.3 to $2.7 \& 6.3$ to $3.1 \operatorname{logs}$, respectively (Figure 2). Whereas, in secondary treated wastewater, the concentration of bacteria decreased from 3.9 to $2.1 \& 3.9$ to $2.3 \operatorname{logs}$, respectively (Figure 2). In general, $50 \mathrm{CuNPs}$ showed comparatively greater bactericidal effects than the 100 CuNPs. Besides NPs size, the exposure conditions also appear to influence the antibacterial efficacy of CuNPs. Discontinuation of mixing resulted in increased bacterial concentrations in both primary and secondary treated wastewater samples. The high organic matter contents in these water samples supported the bacterial regrowth. However, resumption of mixing after $72 \mathrm{hr}$, again resulted in declined concentration of bacteria in both samples. The results highlight the role of the appropriate mixing conditions that ensures constant contact between the bacterial cells and the biocidal CuNPs.

Furthermore, the antibacterial impact of 50 CuNPs on E. coli in the sterilized primary and secondary treated wastewater samples was investigated. After $2 \mathrm{hr}$ mixing with 
50 CuNPs, E. coli concentration in the sterilized primary and the sterilized secondary treated wastewater decreased by 4.5 and $3.4 \mathrm{log}$, respectively (Figure 3). However, under both conditions, the concentration of $E$. coli increased after mixing was stopped for $24 \mathrm{hrs}$, and it continued to increase until mixing was restarted. This increase in bacterial numbers is thought to be due to the high level of organic matter in these samples which might have supported bacterial regrowth. Termination of mixing resulted in a rapid deposition of CuNPs at the bottom of the reactor while bacterial cells remained suspended in solution. The fact that antibacterial effect against $E$. coli is observed only under appropriate mixing condition, suggesting that CuNPs physical proximity to bacterial cells is critical for exerting bactericidal effect. Presence of CuNPs sediments at the bottom of the reactor did not have any bactericidal impact on planktonic bacterial population suspended in solution. The results clearly highlight the importance of appropriate mixing conditions under laboratory conditions and turbulence in aquatic system for continued biocidal impact of CuNPs in ecosystem. 
bioRxiv preprint doi: https://doi.org/10.1101/2021.11.30.470660; this version posted November 30,2021 . The copyright holder for this preprint (which was not certified by peer review) is the author/funder, who has granted bioRxiv a license to display the preprint in perpetuity. It is made available under aCC-BY-ND 4.0 International license.
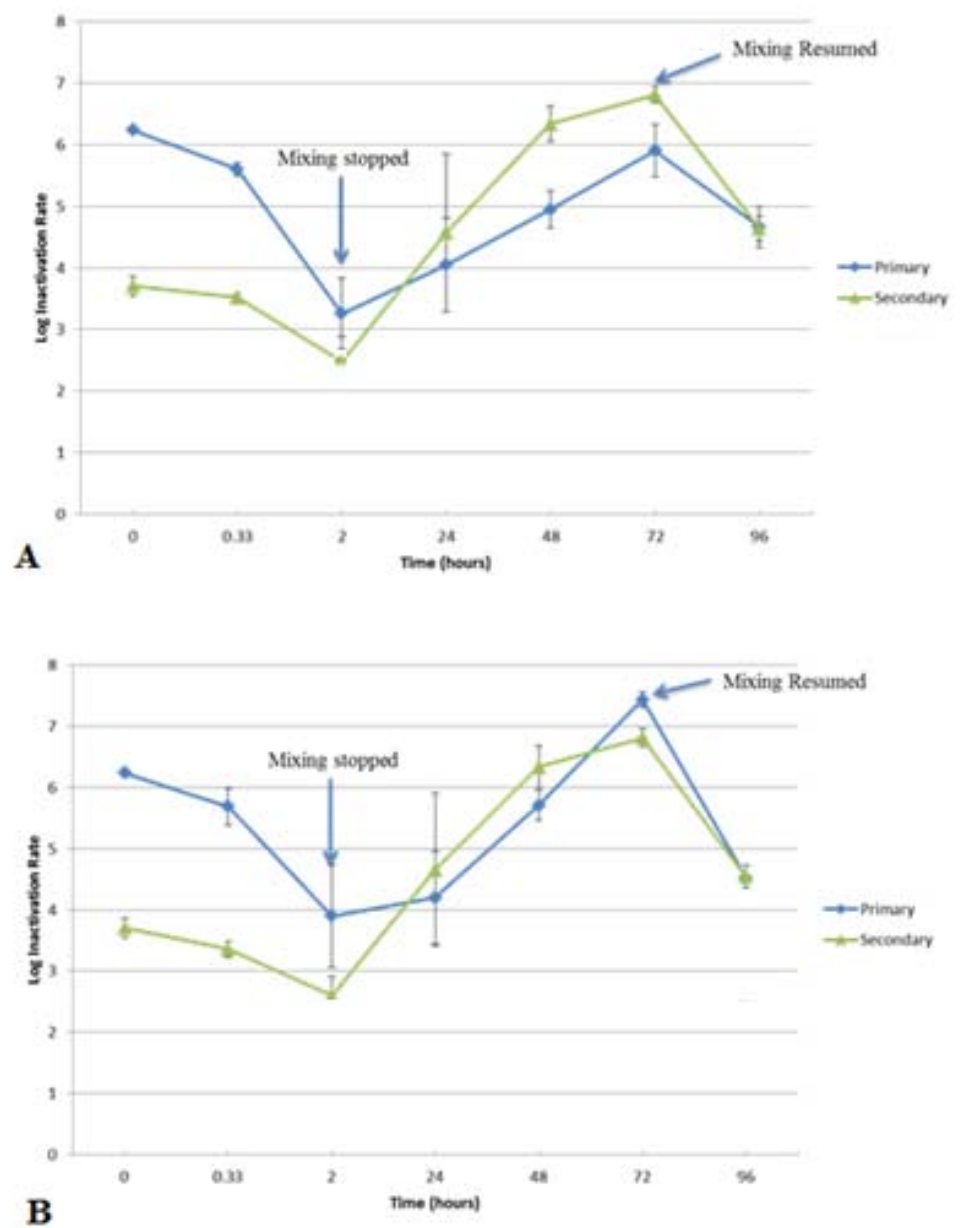

Figure 2 Effects of mixing conditions on the antibacterial efficacy of CuNPs in the primary and secondary treated wastewater samples, A) 50 CuNPs, B) 100 CuNPs.

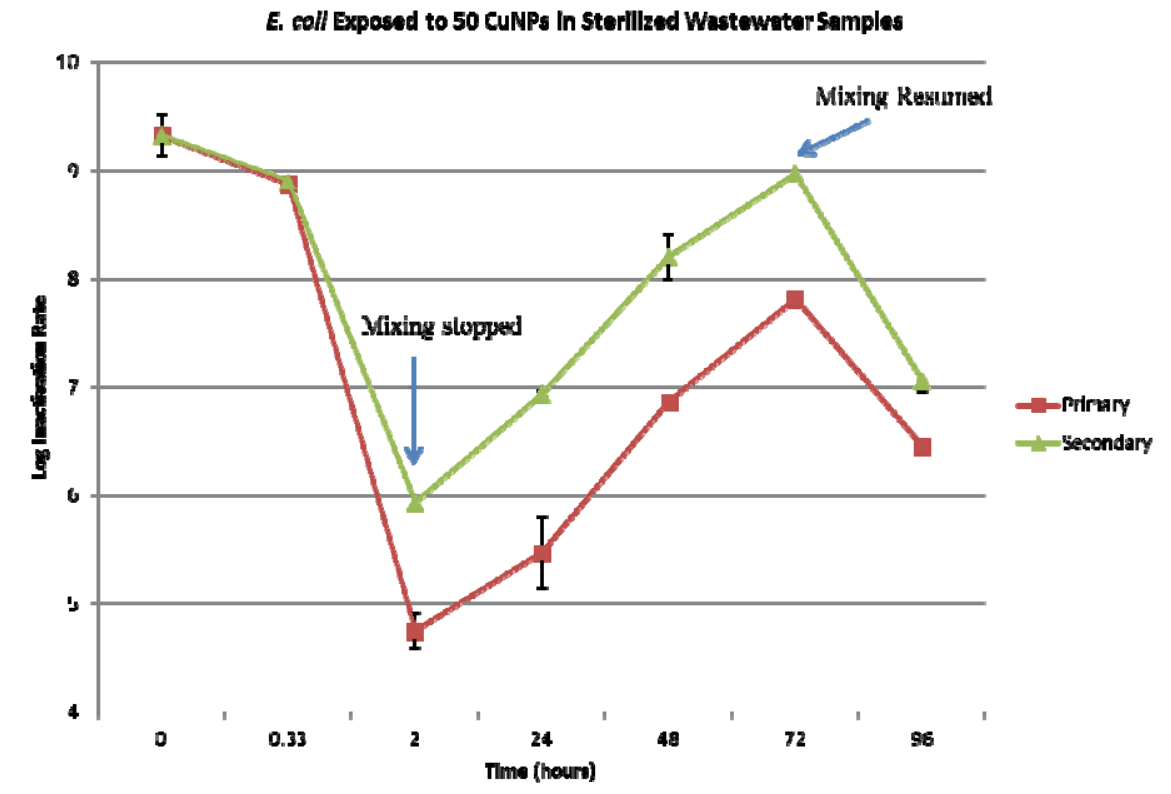


Figure 3. Impact of mixing conditions on the biocidal efficacy of $50 \mathrm{CuNPs}$ against $E$. coli in the sterilized primary and secondary treated wastewater samples.

\section{Toxicity Pathways}

LDH Assay: CuNPs toxicity against gram+ and Gram- bacteria was studied using LDH assay. Exposure to 50 CuNPs resulted in decreased LDH levels in all the bacterial isolates investigated in this study except for Pseudomonas, (Table 2). The total LDH activities inversely correlated to the total viable cells remaining in the sample at any specified time. In the laboratory isolate of Bacillus, slightly lower LDH activities were noted compared to other laboratory bacterial isolates. This could be due to the difference in the stress response pathway used by bacterial strains to handle elevated levels of copper in cell. For example, copper stress results in the expression of copper-binding proteins (CuBPs) on the surface of some bacterial species such as Pseudomonas and Vibrio; however, no such CuBPs are expressed on the surface of Bacillus (Rensing and Gross, 2003). Therefore, further molecular work is required to determine exact nature of such responses by different bacterial strains.

\begin{tabular}{|l|c|c|}
\hline \multicolumn{3}{|c|}{ Table 2: Elicitation of LDH activities in bacterial strains exposed to 50 and } \\
100 CuNPs for 120 min. \\
\hline Strain & 50 CuNPs & 100 CuNPs \\
\hline Bacillus (Lab. Isolate) & $\downarrow$ & $\downarrow$ \\
\hline Bacillus (Field Isolate) & $\downarrow$ & $\downarrow$ \\
\hline Alcaligenes (Lab. Isolate) & $\downarrow$ & $\downarrow$ \\
\hline Pseudomonas (Lab. Isolate) & $\leftarrow \rightarrow$ & $\downarrow$ \\
\hline
\end{tabular}

Note: $\downarrow=$ decrease. $\leftarrow \rightarrow=$ No change 

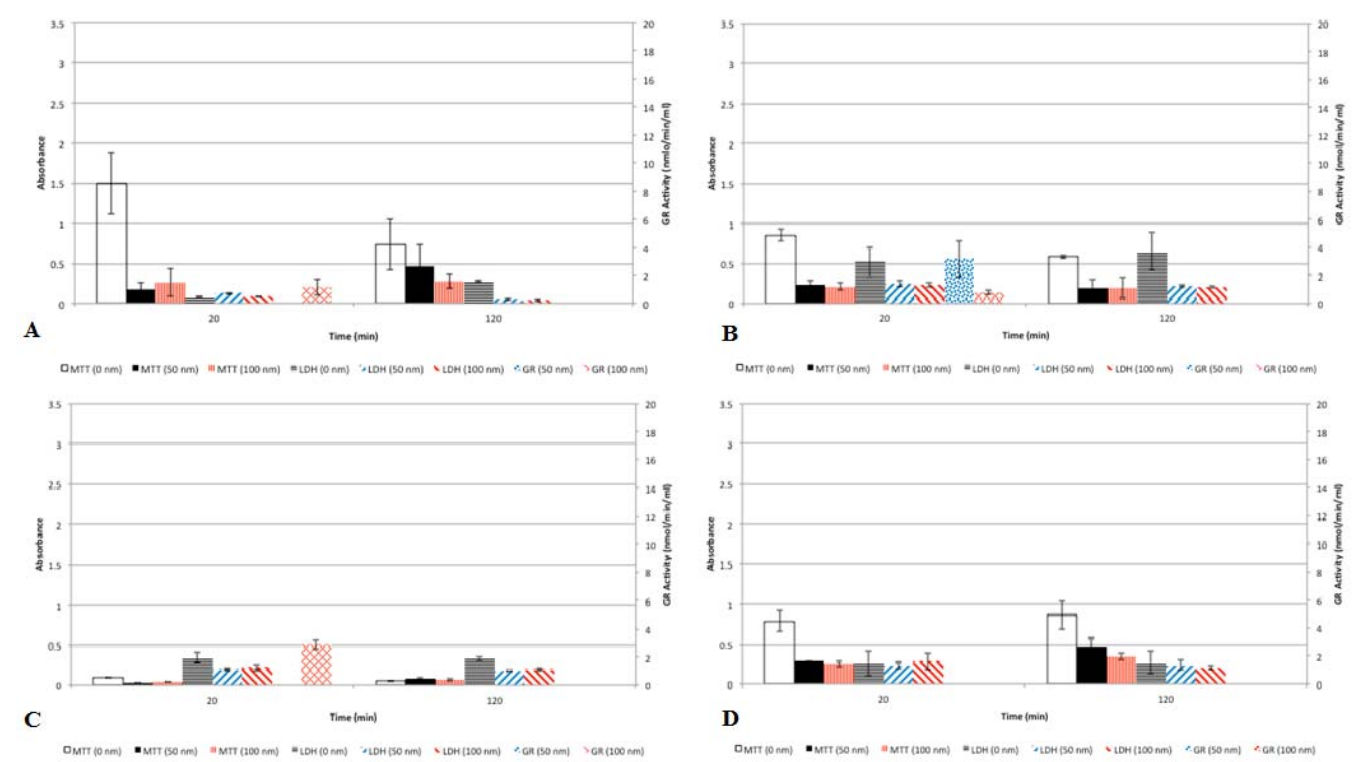

Figure 4. Metabolomic profile of bacteria after 120 min exposure to CuNPs, A) Bacillus laboratory isolate, B) Bacillus environmental isolate, C) Alcaligenes laboratory isolate, D) Pseudomonas laboratory isolate.

GR Assay: Impact of CuNPs exposure on glutathione reductase levels in the bacterial cells was studied. Exposure to 100 CuNPs resulted in elevated GR activities in field and laboratory isolates of Bacillus; however, exposure to 50 CuNPs caused such effect only in field isolate of Bacillus and not the laboratory isolates (Figure 4).

Similarly, exposure to 100 CuNPs provoked elevated GR activity in Alcaligenes cells; however, exposure to $50 \mathrm{CuNPs}$ did not produce such response. In general, the GR activities declined over exposure time. In case of Pseudomonas, GR activities remained unchanged after exposure to 50 and $100 \mathrm{CuNPs}$. The variations in GR induction levels among different species could be caused by many factors. For example, part of the glutathione may be derived from the culture medium consisting yeast extracts that are ordinarily rich in glutathione. Even though samples were washed, it is possible some glutathione from medium may still be attached to bacterial cells and interfered with the GR determinations. In addition, GR activities are species- 
specific, a wide range of bacteria lack glutathione while others may have a very small concentrations (Fahey et al., 1978).

MTT Assay: The impact of CuNPs exposure on bacterial energy metabolic pathways was studied using MTT as endpoint. In general, with increasing exposure time, the MTT activity increased in laboratory isolates of Bacillus, Alcaligenes, and Pseudomonas and decreased in field isolate of Bacillus (Figure 4). The levels of MTT activity in Alcaligenes cells were relatively low compared to the other bacterial strains included in this study. These results indicate that CuNPs may impact at different levels of energy pathway in different bacterial isolates.

\section{Release of $\mathrm{Cu}^{2+}$ from CuNPs}

The release of $\mathrm{Cu}^{2+}$ from CuNPs in aqueous solution ( $0.5 \mathrm{M}$ PBS buffer) were examined and no detectable concentrations of $\mathrm{Cu}^{2+}$ were recorded under the conditions tested in this study (Table 3). Even extended exposure up to 200 hours did not result in release of any detectableCu ${ }^{2+}$; however, a light-blue precipitate was formed at the bottom of the solution (Data not shown). The blue precipitate is copper hydroxide $\left(\mathrm{Cu}(\mathrm{OH})_{2},\right)$ which is formed by the reaction of $\mathrm{Cu}^{2+}$ ions with $\mathrm{OH}^{-}$ions in water. This is an indication of $\mathrm{Cu}^{2+}$ ions release from CuNPs in aqueous solution; however, it is assumed that they are released at a slow rate and instantly react with $\mathrm{OH}^{-}$ions in water, minimizing their possible role in bacterial inactivation. 
Table 3: Kinetics of $\mathrm{Cu}^{2+}$ release from $50 \& 100 \mathrm{~nm} \mathrm{CuNPs}$ in $0.5 \mathrm{M}$ PBS

\begin{tabular}{|c|c|c|c|c|c|c|c|c|c|}
\hline \multicolumn{10}{|c|}{$\mathrm{Cu}^{2+}$ Concentration at $25^{\circ} \mathrm{C}$ exposed to light } \\
\hline & \multicolumn{3}{|c|}{ pH 7.44} & \multicolumn{3}{|c|}{ pH 6.5} & \multicolumn{3}{|c|}{$\mathrm{pH} 8.5$} \\
\hline \multirow{3}{*}{$\begin{array}{l}\text { Contact } \\
\text { Time } \\
\text { (min) }\end{array}$} & \multicolumn{3}{|c|}{$\mathrm{Cu}^{2+}$ Concentration $(\mathrm{M})$} & \multicolumn{3}{|c|}{$\mathrm{Cu}^{2+}$ Concentration $(\mathrm{M})$} & \multicolumn{3}{|c|}{$\mathrm{Cu}^{2+}$ Concentration $(\mathrm{M})$} \\
\hline & \multicolumn{3}{|c|}{ CuNPs $(\mathrm{nm})$} & \multicolumn{3}{|c|}{ CuNPs $(\mathrm{nm})$} & \multicolumn{3}{|c|}{ CuNPs $(\mathrm{nm})$} \\
\hline & Control & 50 & 100 & Control & 50 & 100 & Control & 50 & 100 \\
\hline 20 & \multirow{5}{*}{ ND } & \multirow{5}{*}{ ND } & \multirow{5}{*}{ ND } & \multirow{4}{*}{ ND } & 6.9E-07 & $1.1 \mathrm{E}-06$ & \multirow{5}{*}{ ND } & \multirow{5}{*}{ ND } & \multirow{5}{*}{ ND } \\
\hline 40 & & & & & 7.9E-07 & $1.0 \mathrm{E}-06$ & & & \\
\hline 60 & & & & & 7.9E-07 & $1.2 \mathrm{E}-06$ & & & \\
\hline 90 & & & & & 3.4E-07 & 7.9E-07 & & & \\
\hline 120 & & & & $4.1 \mathrm{E}-08$ & ND & 4.4E-07 & & & \\
\hline \multicolumn{10}{|c|}{$\mathrm{Cu}^{2+}$ Concentration at $37^{\circ} \mathrm{C}$ exposed to light } \\
\hline \multirow{4}{*}{$\begin{array}{l}\text { Contact } \\
\text { Time } \\
\text { (min) }\end{array}$} & \multicolumn{3}{|c|}{ pH 7.4 } & \multicolumn{3}{|c|}{ pH 6.5} & \multicolumn{3}{|c|}{ pH 8.5} \\
\hline & \multicolumn{3}{|c|}{$\mathrm{Cu}^{2+}$ Concentration $(\mathrm{M})$} & $\mathrm{Cu}^{2+} \mathrm{C}$ & oncentrati & ion $(\mathrm{M})$ & $\mathrm{Cu}^{2+} \mathrm{C}$ & ncentratic & on $(\mathrm{M})$ \\
\hline & & uNPs (nn & & & uNPs (nm & & & גNPs (nm & \\
\hline & Control & 50 & 100 & Control & 50 & 100 & Control & 50 & 100 \\
\hline 20 & & ND & $N D$ & ND & 8.9E-07 & $1.3 \mathrm{E}-06$ & ND & $1.2 \mathrm{E}-06$ & 1.7E-06 \\
\hline 40 & & $3.5 \mathrm{E}-08$ & & 7.9E-07 & $2.0 \mathrm{E}-06$ & 2.3E-06 & 7.9E-07 & $2.3 \mathrm{E}-06$ & 2.3E-06 \\
\hline 60 & ND & 2.4E-07 & 4.9E-07 & $1.2 \mathrm{E}-06$ & 2.4E-06 & 2.5E-06 & $1.5 \mathrm{E}-06$ & $2.7 \mathrm{E}-06$ & 3.3E-06 \\
\hline 90 & & $4.9 \mathrm{E}-07$ & $6.4 \mathrm{E}-07$ & $1.2 \mathrm{E}-06$ & $2.2 \mathrm{E}-06$ & $2.1 \mathrm{E}-06$ & $1.4 \mathrm{E}-06$ & $3.1 \mathrm{E}-06$ & $3.1 \mathrm{E}-06$ \\
\hline 120 & 2.9E-07 & 8.4E-07 & 8.9E-07 & \begin{tabular}{|l}
$1.6 \mathrm{E}-06$ \\
\end{tabular} & $2.5 \mathrm{E}-06$ & 2.1E-06 & 1.9E-06 & $3.4 \mathrm{E}-06$ & 3.4E-06 \\
\hline & & & $\mathrm{Cu}^{2+} \mathrm{Cr}$ & oncentrati & ion at $25^{\circ} \mathrm{C}$ & C, Dark & & & \\
\hline & & pH 7.4 & & & pH 6.5 & & & pH 8.5 & \\
\hline Contact & $\mathrm{Cu}^{2+} \mathrm{C}$ & oncentrati & ion (M) & $\mathrm{Cu}^{2+} \mathrm{C}$ & oncentrati & ion (M) & $\mathrm{Cu}^{2+} \mathrm{C}$ & ncentratic & on $(\mathrm{M})$ \\
\hline (min) & & CuNPs (nn & & & CuNPs (nm & & & גNPs (nm & \\
\hline & Control & 50 & 100 & Control & 50 & 100 & Control & 50 & 100 \\
\hline 20 & & & & & & & & & \\
\hline 40 & & & & & & & & & \\
\hline 60 & ND & ND & ND & ND & ND & ND & ND & ND & ND \\
\hline 90 & & & & & & & & & \\
\hline 120 & & & & & & & & & \\
\hline & & & $\mathrm{Cu}^{2+} \mathrm{C}$ & oncentrati & ion at $37^{\circ}$ & C, Dark & & & \\
\hline & & pH 7.4 & & & pH 6.5 & & & pH 8.5 & \\
\hline Contact & $\mathrm{Cu}^{2+} \mathrm{C}$ & oncentrati & on $(\mathrm{M})$ & $\mathrm{Cu}^{2+} \mathrm{C}$ & oncentrati & on $(\mathrm{M})$ & $\mathrm{Cu}^{2+} \mathrm{C}$ & ncentratic & on $(\mathrm{M})$ \\
\hline (min) & & ZuNPs (nn & & & CuNPs (nm & & & ANPs (nm & \\
\hline & Control & 50 & 100 & Control & 50 & 100 & Control & 50 & 100 \\
\hline 20 & & $6.0 \mathrm{E}-08$ & $1.1 \mathrm{E}-07$ & $5.1 \mathrm{E}-07$ & $1.5 \mathrm{E}-06$ & $1.6 \mathrm{E}-06$ & & & \\
\hline 40 & & 2.6E-07 & $4.1 \mathrm{E}-07$ & $1.4 \mathrm{E}-06$ & $1.3 \mathrm{E}-06$ & $1.2 \mathrm{E}-06$ & & & \\
\hline 60 & ND & $3.1 \mathrm{E}-07$ & $3.1 \mathrm{E}-07$ & $1.0 \mathrm{E}-06$ & $1.2 \mathrm{E}-06$ & $1.6 \mathrm{E}-06$ & ND & ND & ND \\
\hline 90 & & $2.6 \mathrm{E}-07$ & 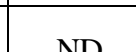 & $8.1 \mathrm{E}-07$ & $1.3 \mathrm{E}-06$ & $9.6 \mathrm{E}-07$ & & & \\
\hline 120 & & NID & ND & $7.6 \mathrm{E}-07$ & $6.1 \mathrm{E}-07$ & $5.6 \mathrm{E}-07$ & & & \\
\hline
\end{tabular}

*ND: No Ions Detected 


\section{Conclusions}

CuNPs play a significant role in many new technologies and their use has expanded rapidly over the last recent decades. Most studies on environmental impact of CuNPs have been focused on laboratory strains of bacteria. This study focuses on comparison between laboratory and wastewater isolates of gram-positive and gram-negative bacteria. Subtle differences in the response of laboratory and environmental bacterial isolates and inter-species variations in response to CuNPs were recorded. The study identifies differences in the toxicity elicitation pathway of CuNPs in different bacterial species. Additional studies are recommended for further understanding of these pathways by gene silencing studies, which were beyond the scope of this work.

\section{References}

Alum, A., A. Alboloushi and M. Abbaszadegan. 2018. Copper nanoparticles toxicity: Laboratory strains verses environmental bacterial isolates. Journal of Environmental Science and Health Part A 53(4):1-8

Aruoja, V., Dubourguier, H. C., Kasemets, K., \& Kahru, A. (2009). Toxicity of nanoparticles of $\mathrm{CuO}, \mathrm{ZnO}$, and $\mathrm{TiO}_{2}$ to microalgae Pseudokirchneriella Subcapitata. Science of The Total Environment, 407: 1461-1468

Aruoja, V., Pokhrel S., Sihtmae, M., Mortimer, M., Madler, L., Kahru A. 2015. Toxicity of 12 metal-based nanoparticles to algae, bacteria and protozoa. Environ. Sci.: Nano, 2: 630-644

Bhuvaneshwari, M., Bairoliya, S., Parashar, A., Chandrasekaran, N., Mukherjee, A. 2016. Differential toxicity of $\mathrm{Al}_{2} \mathrm{O}_{3}$ particles on Gram-positive and Gram-negative sediment bacterial isolates from freshwater. Environ. Sci. Pollut. Res., 23: 1209512106

Brown, N. L., Barrett, S. R., Camacaris, J., Lee, B. T. O. \& Rouch, D. A. (1995). Molecular genetics and transport analysis of the copper resistant determinant (pco) from Escherichia coli plasmid pRJ1004. Molecular Microbiology, 17(6), 1153-1166.

Denier van der Gon H, Hulskotte H, Visschedijk AJH, Schaap M. (2007). A revised estimate of copper emissions from road transport in UNECE-Europe and its impact on predicted copper concentrations. Atmos Environ. 41:8697-8710. doi: 10.1016/j.atmosenv.2007.07.033. 
EPA - US Environmental Protection Agency. 2003. Workshop on Nanotechnology and the Environment. August 28-29, 2002. Arlington, Virginia. P50-51 EPA/600/R02/080.

Fahey, R. C., Brown, W. C., Adams, W. B., \& Worsham, M. B. (1978). Occurrence of glutathione in bacteria. Journal of Bacteriology, 1126-1129

Grigratos T, and G Matini (2015). Brake wear particle emission review 2015. Environ Sci Pollut Res 22:2491-2504

Joonas, E. , Aruoja, V. , Olli, K. 2019. Environmental safety data on $\mathrm{CuO}$ and TiO2nanoparticles for multiple algal species in natural water: Filling the data gaps for risk assessment. Science of the Total Environment 647: 973-980

Kim, J. S., Adamcakova-Dodd, A., O'Shaughnessy, P. T., Grassian, V. H. \& Thorne, P. S. (2011). Effects of copper nanoparticle exposure on host defense in a murine pulmonary infection model. Particle and Fibre Toxicology, 8, 29 doi:10.1186/17438977-8-29

Gilbertson, L. M., Albalghiti, E. M., Fishman, Z. S., Perreault, F., Corredor, C., Posner, J. D., Elimelech, M., Pfefferle, L. D., and Zimmerman, J. B. ShapeDependent Surface Reactivity and Antimicrobial Activity of Nano-Cupric Oxide. Environmental Science \& Technology 201650 (7), 3975-3984

Ren, G., Hu, D., Cheng, E. W. C., Vargas-Reus, M. A., Reip, P. \& Allaker, R. P. (2009). Characterization of copper cxide nanoparticles for antimicrobial applications. International Journal of Antimicrobial Agents, 33, 587-590.

Rensing, C. \& Grass, G. (2003). Escherichia coli mechanisms of copper homeostasis in a changing environment. FEMS Micriobiology Reviews, 27(2-3), 197-213

Roco, M. C. (2007) The NNI: Past, Present and Future. 2nd edition. Boca Raton and London: CRC, Taylor and Francis; 2007

Westerhoff, P. K., Kiser, A., Benn, T. M. (2009). Detection of titanium dioxide in wastewater treatment plants. 237th ACS National Meeting, Salt Lake City, 25 March. 